\title{
THE MATERIALITY OF MARRIAGE IN THE ARTISAN COMMUNITY OF RENAISSANCE VERONA*
}

\author{
ZOE FARRELL \\ University of Cambridge
}

\begin{abstract}
The implicit view in many studies of Renaissance culture is that only the very wealthy were able actively to participate in, and to influence, the changing market for consumer goods. However, in recent years there has been an increasing awareness of the importance of studying the material culture of the non-elite. Building on the work of historians such as Sandra Cavallo, Paula Hohti and Isabella Palumbo Fossati Casa, this article explores the items within the dotal inventories of the wives and daughters of artisans in sixteenth-century Verona. Through an analysis 100 inventories, it will be argued that during the sixteenth century, artisans and their families played an active role in the burgeoning market for consumer goods. Even in provincial cities such as Verona, artisans were able to own vast numbers of commodities, which were at once practical, luxurious and devotional, that functioned to increase both the comfort and splendour of the household. Dotal inventories are an underused source; however, this article will demonstrate how they can shed light on the material culture of the non-noble classes in the Renaissance.
\end{abstract}

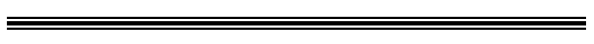

Murray Edwards College, Cambridge, CB3 ODF,zf230@cam.ac.uk

* I would like to thank, amongst others, Professor Mary Laven, Dr Beatrice Zucca Michaletto, Professor Edoardo Demo, Professor Paola Lanaro, and the Director and staff at the Archivio di Stato di Verona, for their advice in the production of this article. I would also like to thank the reviewers of this article for their insightful and constructive feedback. This article was supported by generous scholarships from the Gladys Krieble Delmas Foundation, Murray Edwards College and the Cambridge Trust. 
During the sixteenth century, Verona was one of the largest and wealthiest cities under Venetian rule in the Terraferma. Advantageously positioned on the Adige river, and protecting the entrance to a major Alpine pass, Verona acted as an intermediary for trade across Italy and the rest of Europe. However, the city has attracted little attention from historians of the Renaissance in Italy. It is unsurprising, therefore, that the role of Verona's artisans in participating in the culture of the Renaissance has been overlooked. For many years, the underlying assumption in studies of early modern consumerism was that only elites were able to engage significantly with the changing market for consumer goods. ${ }^{1}$ However, there is an increasing awareness of the importance of the non-noble classes in changing attitudes towards consumption, luxury and domestic life in the Renaissance. It has become clear that both noble and non-noble households possessed a wide range of material artefacts which acted to confer status onto the owner. ${ }^{2}$ This was particularly important for the socially mobile artisan who, as the maker of consumer goods, was at the heart of the development of Renaissance material culture. ${ }^{3}$ Marriage, within this structure, was an important occasion for artisans, their wives and daughters, to build familial relations and augment positions within their community. As Ulinka Rublack has argued, social identity could be adjusted at the point of marriage through the consumption of specific material commodities. ${ }^{4}$ The dowry and the legal protections surrounding it acted as both codifier and store for such material possessions.

What follows is a detailed investigation into the objects found within the dotal inventories of the wives and daughters of artisans in sixteenth-century Verona. This article will investigate the material world of the artisan's home and the objects within it through an analysis of 100 dotal inventories found in the Atti dei Rettori Veneti a Verona; highlighting the range of practical, aesthetic and luxurious goods found within them. The dowry was amongst the most significant forms of marital exchange in early modern Italy. As such, dotal contracts have been analysed by many historians seeking to understand more about the 
financial and social consequences of dowry culture, such as price inflation, enforced claustration and the problems women had in gaining control over their dowries. ${ }^{5}$ However, research into dowries often overlooks the contents of the dotal inventory, in particular, the beni mobili, or, moveable goods, associated with them.

In Verona, dowries were customary amongst all classes, and whilst there was a large difference in the value given by the nobility and by those within the popular classes, in every case a suitable dowry was necessary in ensuring an appropriate match for daughters. ${ }^{6}$

Dowries were intended under Roman law to assist the husband in the care of his new wife and family; however, in late medieval Italy, they had come to be accepted as a woman's stake in her father's patrimony, or 'pre-mortem inheritance'. ${ }^{7}$ However, whilst the wife had rights over her dowry analogous to an owner, she was not in possession of it. The dowry was instead managed by her husband during marriage, although he was required to manage it in the interests of his wife. ${ }^{8}$

There were, however, a series of legal protections which guarded women against loss of their property at the hands of their husbands. First and foremost, women had a right to restitution of their dowry upon dissolution of their marriage. ${ }^{9}$ There were also legal protections to ensure that such future restitution remained a possibility. In particular, dowries were often secured against the property of the husband to protect against risk. ${ }^{10}$ During marriage, a wife's privilege over preservation of her dowry took precedence over any other privilege, such as, for example, that of creditors seeking to claim funds from her husband's estate. ${ }^{11}$ Stanley Chojnacki has argued that the woman's right to restitution of her dowry was so significant that most husbands actively guaranteed it on their own estate (or in the case that this was insufficient, on that of their kin). ${ }^{12}$ Stefania Montemezzo has similarly argued that in Verona women were encouraged to get dowry security, which protected from loss of 
their property and thus their honour in widowhood, as well as protecting society from a breakdown in the dotal system. ${ }^{13}$

Furthermore, a wife did not have to wait for dissolution of her marriage to reclaim her dowry. In the event that a woman, or her natal family, felt that her husband was mismanaging the dowry, or if her husband was verging on poverty, thus threatening the restitution of her dowry, a woman had the legal remedy of vergens ad inopiam. Julius Kirshner has argued that the reaffirmation of this Roman law in a number of Italian states allowed women to 'reclaim' their original dowry during marriage, or to 'lay claim to an equivalent amount of the husband's goods', which protected assets. ${ }^{14}$ This system was, however, open to abuses, with some husbands seeking to have their goods transferred into the possession of their wives, so as to shield them from creditors. ${ }^{15}$ According to Kirshner, the differences between legitimate and illegitimate claims were difficult to distinguish and thus a number of governments required insolvency of claimants to be made public, thus deterring those wishing to abuse the system. ${ }^{16}$ Overall, wives seem to have had considerable leverage over their dowries and the preservation of their patrimonies. Whilst systems were also in place to limit women's autonomy over their possessions during marriage, significant legal protection remained in place to protect them, but more so to protect the integrity of a system that was deemed fundamental to a well-functioning society.

Analysis of legal documentation relating to dowries, their protection and their restitution, can illuminate aspects beyond the dowry itself. In particular, dotal inventories are useful tools in helping us to understand more about the goods within the homes of dowered women and their husbands during the Renaissance. Legal documentation relating to the protection of dowries can be found in abundance within the archives of Verona, especially among the records of the Atti dei Rettori Veneti a Verona. These records contain the proceedings of the judicial offices of Verona, which were headed by the Venetian rectors 
within the city. ${ }^{17}$ The 100 inventories chosen for this investigation relate to dowry estimation, dowry security and dowry restitution, all including a list of domestic items documented by a public notary. They date from the period 1561 to 1596 , although the marriages they relate to often occurred much earlier, as testified by the information in the opening of many of the documents, with the earliest date mentioned being $1536 .{ }^{18}$ While the documents consistently provide the name of the woman, her husband and usually the date on which the marriage contract was drawn, some examples are more informative about the reason for which the inventory was made. The inventory of Magdalena, wife of a smith, for example, states that the goods listed were intended for her conservation lest her husband fall into poverty (' $o b$ vergentiam ... ad inopiam'). ${ }^{19}$ What unites these documents is the underlying purpose to ensure the preservation of the dowry.

Although underutilised as a historical source, such inventories are often rich and detailed stores of information. In the first instance, many of these Veronese dotal inventories list the estimated value of each item, which is rare in contemporary post-mortem inventories in the Veneto. Secondly, they normally describe the condition of each item, recording if items were in good or new condition, or conversely, used and old. Moreover, the high number that survive from the non-noble classes provide a wealth of information about a previously understudied group. Of course, dotal inventories also have their limitations. ${ }^{20}$ There is often uncertainty as to whom the goods eventually belonged, as well as to the ruling in individual cases. Similarly, there is scarcely ever an indication of where in the household these items would have been kept - whether they were for public view, or whether they were more private objects. Nevertheless, dotal inventories are an invaluable source for the historian of material culture and particularly for those researching the non-elites of Italian Renaissance towns and cities. Through these documents concerning the protection and preservation of 
dotal assets, it is possible to gain an insight into the domestic world of married couples in the Renaissance.

The sources chosen for this investigation are those which list the profession of the husband or father of the woman whose dowry was being protected, where this profession falls within the category of 'artisan' ${ }^{21}$ As such, those without professions listed, as well as those with noble titles, and those professions such as notaries, doctors and merchants, have not been included in the sample. Artisans were a heterogeneous group, ranging from wealthy masters in prestigious trades, to day labourers, working in multiple sectors. ${ }^{22}$ Within the artisan class there were huge degrees of variation in terms of wealth, with those in the silk industry generally commanding the highest pay, and those in more quotidian occupations, such as weavers and bakers, often less well-off. ${ }^{23}$ In general, the term artisan refers to those within the popular classes whose work focused primarily in the realms of production. ${ }^{24}$ However, there were also those who were involved in the process of managing workmen under their charge, and a number of entrepreneurial artisans who may have started by making items themselves, but whose business expanded as they took on multiple outlets. Most artisans also traded in their products, playing a key role in the exchange of these goods amongst people of different social groupings. ${ }^{25}$ In order to achieve the greatest understating of the variation in the lives of those involved in production within the city, a broad spectrum of trades has been considered in this analysis, ranging from bakers, to carpenters, and tailors (see table 1). ${ }^{26}$ 
Table 1: List of different occupations in the sample of dotal inventories

\begin{tabular}{|l|r|l|r|l|r|l|r|}
\hline Weaver & 8 & Cobbler & 2 & Wool comber & 1 & Blacksmith & 2 \\
\hline Hatter & 11 & Potter & 2 & Carpenter & 9 & Wool beater & 1 \\
\hline Shoemaker & 8 & Apothecary & 2 & Carder of wool & 2 & Labourer & 1 \\
\hline Baker & 18 & Flour sorter & 1 & Stove keeper & 1 & Paper maker & 1 \\
\hline Marver & 1 & Carter & 2 & Boatman & 1 & Cloth scraper & 1 \\
\hline Spinner & 3 & Tailor & 10 & Swordsmith & 2 & Barber & 4 \\
\hline Cheesemonger & 6 & Smith & 2 & $\begin{array}{l}\text { Maker of wooden } \\
\text { containers }\end{array}$ & 1 & Dyer of colours & 2 \\
\hline Leather tanner & 3 & 7 & $\begin{array}{l}\text { Worker in samiti } \\
\text { cloth }\end{array}$ & 1 & Butcher & 1 & Furrier \\
\hline
\end{tabular}

The study of inventories presented here suggests that artisans often possessed a wealth of practical, decorative and luxury goods, which served to enhance the public image of the married couple. There is a consistent pattern of goods listed in these inventories, with the vast majority containing similar items of furniture, clothing, jewellery, and table and kitchenware. This suggests that there was an expected norm of the types of commodities a respectable household should possess, and by analysing these inventories, we can begin to understand more about the 'ordinary' Renaissance home. However, what is also clear is that artisans were able to differentiate themselves and the image of their family through the possession of luxurious, or semi-luxurious material items and as such, some of the more exceptional examples of material commodities will be discussed.

It will be argued that artisans played an active role in the burgeoning market for consumer goods in the Renaissance. The idea of a 'consumer revolution' is one which has divided opinion amongst historians, with debate surrounding when, if at all, such a phenomenon took place. Notably, Jan de Vries has argued that there was an 'Industrious Revolution' during the long eighteenth century, during which both the supply of and demand for market-oriented goods increased. ${ }^{27}$ Others, such as Renata Ago and Lorna Weatherill 
have seen the seventeenth century as the key moment in the rise to consumerism in both Italy and England. ${ }^{28}$ Richard Goldthwaite traced the line further back to argue that it was during the Renaissance that the birth of a recognisably modern consumer society occurred ${ }^{29}$ Whilst this article will make no claims to the discovery of a 'consumer revolution', it will add a new body of evidence to the field by arguing that by the sixteenth century, even outside the major centres of Italy, the working people were able to consume a vast array of material objects which were used to increase both the splendour and the comfort of a home. Artisans were at the core of the culture of the Renaissance; they were not only the makers, but also the shapers, and the participants within the transformations of the time. The evidence within this sample illustrates a combination of concern for both comfort and status and in order to unravel this, the following analysis will highlight three key elements of the dotal inventory and thus, the artisan household: furniture, clothing and jewellery. ${ }^{30}$ Here, the devotional, symbolic and aesthetic significance attached to such items will be discussed. 


\section{Qutre ogenping}

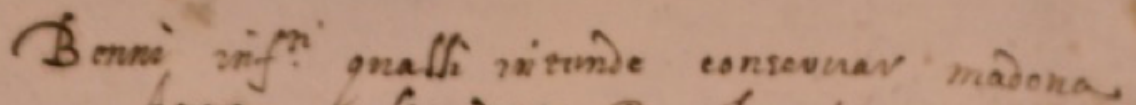

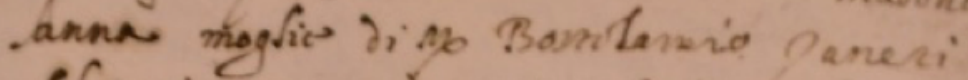
filatovio per asscenratione iellaciera iox,

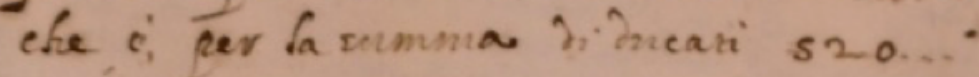
come consta insivumelo guflico -5 $V_{n}$ futto 6 fincioli $n s a \partial^{\circ}-L_{106}-i o$ Tha coifina $\partial i$ seda or una corrertina $-L$ si $-i o$. Brafla 30. rolla dore zvarrevse rasade $L$ s4 -io. Olto camises prie sorn' una camisora $L 48$-io. Rerattio roappi da mano in drappo fillor is -io.

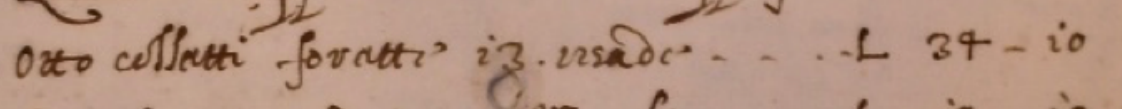
Sni fassc usade emaimagtia - L L is - io. Diesc'fazrofmi da naso brazla is fasso nove

Vna verbla negra Iambuforvusada $L$ io -io. Vna vrb6a negra zalbido usada - L 72 Vna retta panno cromerin ensada -1 as - io. Vna verta pauno zurchin resida $-f$ io $-i o$. Vraverca ormesin commesin urida $L$ to - io. Dre rangafic, fone or 3 ranagfidi $L 20$ io. dere casse nogara fone … 32 io Cordireve afm' massariofe, $\partial i$

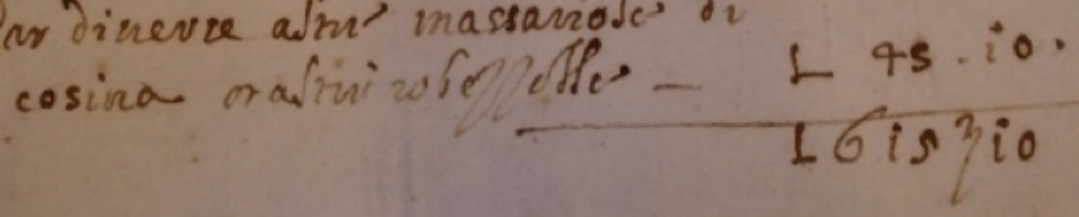

Figure 1: Example of a dotal inventory. ASVr, ARV, b. 149, 6 Feb, 1596, Anna, wife of Bartolamio Zaneti filatorio 
In most instances, dotal inventories begin with furniture, with the bed taking pride of place, followed by storage items such as chest and shelves, tables and chairs. The amount of furniture listed in many of the inventories in this sample would be seen as great even by today's standards and the consistency with which some items of furniture were listed suggests that within the artisan community, it was expected that married couples would have a certain number of particular items in their household as a matter of both necessity and honour. An analysis of the types of furniture within these dotal inventories is therefore useful in helping us to understand more about the domestic environment of the time.

As often the largest piece of furniture in the home, the bed was among the most significant of all moveable goods in the early modern household, both in terms of symbolic status and practical value. They were not only used to accommodate family members, but also at times a point of distinction and a focal point of domestic social interaction. The types of wood used to make the bed, as well as the decoration, carving, and furnishings were all part of a display. ${ }^{31}$ The bed was at the top of the hierarchy of goods and was usually listed together with a mattress or bolster pillow, cushions, covers and linens. It is perhaps not surprising, therefore, that 99 of the 100 inventories analysed include at least one bedstead, mattress, or mattress topper, with most having more than one. It is not uncommon for a dotal inventory to have a large number such items. The high number of beds and bedding items in many of these inventories is perhaps a reflection of their status amongst other moveable goods. ${ }^{32}$

There are several important items related to the bed listed in these inventories. The most commonly mentioned item is the letto, which simply translates as 'bed', but in this time could refer to an over-mattress, often filled with goose-feathers. ${ }^{33} 95$ of the 100 inventories list at least one letto, and in almost all cases, it is the most expensive item. Also common, 
although usually less expensive, is the lettiera, which was a large bedstead, often made of walnut, but sometimes made of cheaper wood such as pine. Lettiere were imposing bed frames and were one of the most popular forms of furniture in the Italian Renaissance. ${ }^{34}$ In addition to this large piece of furniture, many of the inventories also list smaller beds, called cariole, which were portable and slid underneath larger beds during the day. ${ }^{35} 75$ of the sampled inventories include a bedstead such as a lettiera or a cariola. A further 29 inventories also include a separate mattress (materazzo or pagliarizzo). Some of these mattresses (materazzi) would have been filled with wool, whilst pagliarizzi were filled with straw. The inventory of Appolonia, whose husband and father were both bakers, is a good example of the differentiation in values attributed to the different elements of the bed. At the top of the inventory are two letti, the first of which is listed with a bolster (piumazzo) and filled with feathers, valued at 36 lire. The other letto, also stuffed with feathers, is listed with two bolsters and six cushions (cossini), which together are valued at 40 lire. This provides a contrast to the two mattresses (matarazzi) also listed, one of which was stuffed with wool and, together with three cushions, is valued at only 9 lire. Similarly, the two bedsteads themselves, the pinewood (pezzo) lettiere, were painted and valued together at only 5 lire. ${ }^{36}$

There is also a surprising number of beds and bedding accessories in some of the inventories. In the inventory of Margerita, wife of a swordsmith, for example, there are three mattresses (matarazi), three letti, four lettiere of walnut (noghera), a portable bed (cariola) and two further straw mattresses (pagiarizi), in addition to one canopy for a bed (pavilion) ${ }^{37}$ Thus, within their household, Margerita and her husband had four full sized and one smaller bedstead, in addition to five mattresses and three over-mattresses. A similar example comes from the inventory of Catherina, wife of Battista, a shoemaker from Mantua, who had one walnut lettiera, four pinewood lettiere, three small wool mattresses (mattarazzi di lana), and four small letti. ${ }^{38}$ 
As the centrepiece of one of the most important rooms in the home, the bed was not only a utilitarian object, but also a place for artisan men and women to express their virtues through ornamentation and decoration. ${ }^{39}$ In the majority of the inventories analysed, the style and decoration of the bed is not listed. However, in a number of cases the evidence hints at the type of decoration which could be used for these beds. The dotal inventory of Barbera, daughter of a baker and wife of a carver, for example, includes two walnut lettiere, one of which was carved (intagliata). Valued at 10 lire for both, these two bedsteads were significantly cheaper than the letto which, listed together with two bolster pillows and six old cushions, was valued at 46 lire and 10 soldi. ${ }^{40}$ However, the fact that one bed was carved demonstrates that this practical object was also being used as a form of decoration. As well as a letto with a bolster pillow and another pillow, the dotal inventory of Floria, wife of a baker, also includes a painted bedstead and two pillowcases worked with black silk (seda). The two silk pillowcases on their own were valued at 12 lire. ${ }^{41}$ Similarly, Anna, wife of a spinner, had an expensive silk bed cover which, along with another coverlet (coltra di seda e una covertina), was valued at 51 lire. ${ }^{42}$ A number of inventories also mention canopied fabrics for the bed, including that of Libera, daughter of a tailor and wife of a baker, who had amongst the items in her dotal inventory an old canopied structure for her bed made with German fabric (una pavagion vechio tella todescha).${ }^{43}$ As well as providing a practical structure for privacy and to keep insects out, canopied structures were also used to frame the bed and at times were decorated to further accentuate the grandeur of the bed. ${ }^{44}$

Carved and painted chests provided another means by which artisans could embellish their homes. Designed to store and organise the ever-increasing abundance of material objects that were being collected, chests and cases came in many different forms and were one of the most popular types of furniture in Renaissance households at all social levels. ${ }^{45}$ The most common form of chest was the cassa, usually made of walnut or cheaper types of 
wood, such as pine. 96 of the inventories in the sample mention some form of chest, with most listing a number of such items. The inventory of Margerita, the wife of a swordsmith, for example, includes fourteen different casse and forcieri (chests with lock and key), which were together valued at 36 lire ${ }^{46}$ In many cases chests were left plain, or their decoration was not described. However, 42 of the inventories list painted or carved chests. The inventory of Clara, wife of a hatter, catalogues six painted casse, together valued at 5 lire, and five painted forcieri, also valued at 5 lire. ${ }^{47}$ As is the limitation with this type of source, there is usually no description of the type of painting or decoration applied to these chests. The painting could therefore range from highly ornate designs to simple colour blocks. However, what is clear is that these functional objects were often given a decorative effect which made them part of the overall aesthetic of the household. Artisan case were at times colourful places, with many items of furniture painted to brighten up the living space. ${ }^{48}$ The dotal inventory of Lucia, wife of a dyer of hats, for example, includes a bedstead, four chests, a bench and a credenza, all of which were painted. ${ }^{49}$

There were several reasons why chests were a significant part of these inventories. Firstly, they were organisational tools. Artisan homes were often small, consisting of only a number of rooms, including a portego, and usually at least one camera.$^{50}$ Chests served as storage for everything from fine clothing, tapestries and jewellery, to paintings, tableware and food. Equally, artisans might have wished to store material objects away in chests if they had little practical use and were being kept purely as financial investments. ${ }^{51}$ This trend for containment of material goods within chests was something which transcended class boundaries. ${ }^{52}$ Sansovino, when describing the homes of Venetian noblemen, wrote that "there is no person so miserable, with a casa aperta [a well-equipped house in which visitors were received] that he would not have chests and bedsteads of walnut". ${ }^{53}$ This hoarding of objects 
within numerous chests is indicative of a culture which placed importance on the ownership of material commodities.

Equally important to the organisation of a well-equipped home was the provision of seating, so both family and guests could be comfortably entertained. A number of studies into the domestic interior have found that a characteristic which distinguished urban homes from those in the countryside was the prevalence of seating found within them, with those in urban centres having a significant number of items used for seating, even in homes of the lower classes. ${ }^{54}$ This was certainly true for the artisan class in sixteenth-century Verona. 75 of the sample feature some form of chair or stool, with many of the inventories having a high number of individual chairs. Libera, daughter of a tailor and wife of a baker, for example, had twelve regular chairs, or stalls, called scanni, of walnut in her dotal inventory, in addition to four chairs, called cadrege, also of walnut. Similarly, Camilla, wife of a furrier, had a total of eighteen different chairs, including eight cadrege, four of walnut and four with straw seats, and ten scanni. ${ }^{55}$ As well as different types of chairs, many of the inventories also list benches. On top of the six painted chairs (schani) in her inventory, Diamante, daughter of a hosier and wife of a leather tanner, for example, had two painted benches (banche), and three long table benches. ${ }^{56}$ Artisan homes were not only for private use, but places of entertainment for families, guests and patrons. ${ }^{57}$ It was therefore important not only that a home was able to accommodate comfortably a wide range of guests, but also that the home and its objects had a pleasing aesthetic appearance..$^{58}$

Some pieces of furniture listed in the inventories were more overtly decorative, or at least created for the purpose of displaying other objects within the household. During the Renaissance, new types of storage furniture became increasingly popular, with various pieces used for the exhibition of material commodities. Amongst the most significant of these was the credenza, which was a sideboard used for storing and displaying silverware and other 
expensive dining materials. ${ }^{59}$ Such items of furniture would normally be placed near the table and would at times be decorated with fine materials to accentuate the openly displayed tableware. ${ }^{60} 47$ of the sample include at least one credenza. Francesca, wife of a cheesemonger, had two painted credenze in her dotal inventory, valued together at 12 lire. ${ }^{61}$ Similarly, Libera, daughter of a tailor and wife of a baker, had within her inventory two pinewood credenze, one of which was old, valued at 1 lire and 10 soldi, and the other which was painted, and slightly more expensive, at 2 lire and 5 soldi. ${ }^{62}$

Less common, yet still mentioned in 33 of the inventories, is the scancia, which was a type of shelf over which dishes were arranged in kitchens. Scancie, like credenze, were used for storage and display. However, scancie seem to have a clear association with the display of earthenware. Indeed, in many cases, these shelves are listed along with maiolica and different types of pottery. Francesca, the wife of a cheesemonger, for example, had two scancie listed in her dotal inventory, furnished with white maiolica and other maiolica in colour, valued together at 10 lire and 10 soldi. ${ }^{63}$ Julia Poole has argued that demand for maiolica initially came from the middling classes, as the very wealthy preferred silver ${ }^{64}$ However, by the sixteenth century, as innovation led to a higher standard of product and decoration, even the wealthiest of patrons were investing in maiolica tableware, suggesting that its status had risen significantly by this point. ${ }^{65}$ Of course, the value of maiolica varied greatly depending on the producer and, above all, the decoration. Whilst no description of ornate, decorated maiolica was found in this sample, as it is always listed alongside and valued together with the scancie, even at the lower end of the market, maiolica commanded high status and its presence within these inventories demonstrates that in a provincial city like Verona, artisans were able to engage with current consumer trends. ${ }^{66}$ 
Table 2: Number of inventories in which items appear at least once

\begin{tabular}{|l|r|}
\hline Bedsteads, mattresses, and mattress toppers & 99 \\
\hline Chests & 96 \\
\hline Tables and desks & 75 \\
\hline Chairs & 75 \\
\hline Credenze & 47 \\
\hline Scancie & 33 \\
\hline Camise/ camisote & 93 \\
\hline Silk & 38 \\
\hline Veste & 50 \\
\hline Peliza/ pellizon & 62 \\
\hline Items with coral & 42 \\
\hline Rings & 47 \\
\hline
\end{tabular}

\section{III}

When painted, carved, or displayed in a sumptuous manner, furniture could be used to present an image of an honourable home and therefore a respectable identity. However, the most public form of display was dress, and the ownership of a variety of ornate and fine clothing and jewellery was the most direct way in which artisans and their families were able to distinguish themselves. ${ }^{67}$ In the competitive environments of early modern cities, dress was a form of display, where both nobles and artisans alike were willing to invest significant sums on fine attire made from materials such as silk. ${ }^{68}$ The following section will explore the clothing found in the dotal inventories of the wives and daughters of artisans. As with furniture, most of these inventories demonstrate a combination of concern for function and display, with a proliferation of clothing for women, men and children. Even in more provincial cities like Verona, ownership of a variety of fine pieces of clothing was important for those who wished to maintain or to augment a respectable identity. ${ }^{69}$

Clothing was expensive and even plain, worn pieces could command a high value and would have represented a significant financial investment for the modest artisan. Patricia Allerston notes that three shirts brought by a man in early seventeenth-century Venice cost 10 
lire, which would have taken a master craftsman four days to earn ${ }^{70}$ Despite this, it is evident that artisans were able to own large numbers of shirts and gowns. Perhaps the best example of this is camise or camisote, which were shirts, worn by both men and women under garments, found in great abundance in 93 of the inventories analysed. Catherina, wife of a potter, for example, had eight women's shirts, twelve shirts for children and twelve men's shirts in her inventory. ${ }^{71}$ Simona, wife of a tailor had a total of forty-three camise and camisote in her dotal inventory, including ten camise for women, sixteen for men, twelve for children, and five camisote for women, which, taken together were valued at over 93 lire. ${ }^{72}$ Practically, owning such a large amount of basic clothing like these shirts was beneficial as these were gowns which were worn daily underneath outer garments and washed. It was also, however, a financially prudent decision for these artisans as clothing did not significantly lose its value and neither did it incur tax. ${ }^{73}$

As well as an abundance of basic items of clothing, there is also evidence within these inventories that artisans were able to own more luxurious and expensive items. During the sixteenth century, Verona, along with Vicenza, was known for its production of cheaper silks, which provided an alternative to the more expensive, higher quality silks coming out of Venice. ${ }^{74}$ Artisans were involved in the consumption of both more expensive silks, and the newer, cheaper silks, which could provide an imitation of luxury at a lower cost. As well as fabrics described as seda (silk), there are a number of other types of silk within the sample. At the higher end of the scale were silks such as taffeta (tabi), velvet (veludo) and satin (raso or satino). There were then cheaper silks, such as sarcenet (ormesino), which was often used in lining. Whilst artisans undoubtedly played a lesser role in the consumption of silk than the elite in sixteenth-century Verona, both the expensive and cheaper varieties of silk are mentioned in 38 of the sample. ${ }^{75}$ The inventory of Catherina, wife of a potter, for example, includes a gown of silk (seda) with skirt and buttons, valued at 7 lire, ${ }^{76}$ whilst that of Joanna, 
wife of a weaver of wool cloth, includes eight braccia (roughly $64 \mathrm{~cm}$ ) of new silver sarcenet. ${ }^{77}$ Anna, wife of a spinner, had many items of silk in her dotal inventory, including an expensive black taffeta (tabbido) doublet, which even in used condition, was worth seventy-two lire. ${ }^{78}$ In many of these inventories, the items made of silk are small, rather than entire garments, and where silk is present, there is usually only one or two pieces per dowry. Nevertheless, the presence of silks within the sample is testament to the fact that artisans were able to acquire and to use such materials which were regarded by contemporaries as luxurious or semi-luxurious.

One type of silk which features in the sample and would likely have been regarded as a prestigious addition to the household is velvet. ${ }^{79}$ Towards the end of the $1550 \mathrm{~s}$, manufacture of this product had increased and much of the black velvet produced in Verona was exported to areas such as Venice, Bolzano and the Holy Roman Empire. ${ }^{80}$ Evidence within this sample also demonstrates its consumption amongst the artisan community within Verona itself. Iseppa, daughter of a mill keeper and wife of a spinner, for example, had an inventory full of clothing. Amongst a number of everyday items, Iseppa had several more precious and expensive items, such as a pair of black velvet (veludo) sleeves, valued at 10 lire. ${ }^{81}$ The inventory of Camilla, daughter of a mill keeper and wife of a spinner, also includes a gown of yellow cloth with black velvet trim (una vesta di panno zallo con liste di veluto negro), valued at 17 lire. ${ }^{82}$ Items of velvet would have a deep, imposing colour, with a structured, thick texture. Such fabrics would have been instantly recognisable, thus carrying with them a certain sense of grandeur.

The most visible piece of clothing and perhaps the most important piece in terms of public reputation was the over-garment, and evidence within these inventories suggests that these were a central element of artisan consumer culture. As well as providing warmth in colder months, over-garments could also be a sign of distinction. When discussing the gown 
worn by a Venetian nobleman, for example, Cesare Vecellio stated that 'almost all doctors, lawyers, and merchants' wear such items of clothing willingly as they 'confer great dignity' onto those who wear them. ${ }^{83}$ One of the most common types of over-garment was the vesta, which was a long gown worn by both men and women and lined with fur in the winter months. 50 of the inventories list at least one vesta, yet many have more. Camilla, wife of a furrier, for example, had six women's veste, whilst Isabeta, daughter of a baker, had four. ${ }^{84}$ These were basic robes, which could be made to appear luxurious with the use of different fabrics. Simona, wife of a tailor, for example, had amongst the items in her inventory a vesta in blue with a satin trim (lista raso), valued at 19 lire and 8 soldi, ${ }^{85}$ whilst Madalena, daughter and wife of mill-keepers, had in her dotal inventory a vesta of cloth in a deep purple, with a black velvet trim and sleeves, valued at 24 lire (una vesta d pano pavonazzo c $\bar{u}$ liste d veludo negro cū manege vechia). ${ }^{86}$

Another type of over-garment which could offer an outward expression of wealth and taste was the peliza, which was a fur-lined robe and one of the most expensive pieces of clothing an artisan could own. 62 of the sample list at least one peliza. Domenica, wife of a weaver, for example, had a peliza of grey rassa, which was a type of coarse woollen cloth, valued at 22 lire and 10 soldi, as well as another, older and cheaper peliza, with a half-silk covering (coperta di mezo seda). ${ }^{87}$ In this case, the grey cloak is the single most expensive item in Domenica's inventory. Ingela, the daughter of a carpenter, also had in her inventory an old peliza, covered in pink satin, with green trim, valued at 13 lire and 10 soldi (una pelizza coperta $d$ satin rosin vechia lista verde). ${ }^{88}$ Such items were a practical addition to a household, however, they also demonstrated wealth and fashion, conferring a certain amount of status onto the wearer.

Other items of clothing could also be used as tools for establishing position, particularly when full of colour and adorned with fine fabric. Frequently mentioned items of 
clothing include shoes and hose, doublets and hats, and it is vital that we take these items into account when reconstructing the domestic environment of the artisan class. ${ }^{89}$ Whilst many of these items lack description in the inventories, some cases of elaboration on fabrics or style can be found. Bartholomea, wife of a mason, for example, had within her inventory a cape (capa) and a pair of hose of chamois (cammozo), which was a soft, pliable leather, with their own upper-stockings (li suoi scoffoni), valued together at 25 lire. ${ }^{90}$ Similarly, Libera, daughter of a tailor and wife of a baker, had a man's cape in ash colour, and two pairs of matching hose (una capa da homo beretina, e due para calze beretine), which were listed with two doublets (ziponi) and together valued at 18 lire. ${ }^{91}$ Appolonia, whose father and husband were both bakers, had within her inventory a pair of dark red hose with their upperstockings, with a velvet trim (un paro d calze de pano morelo cū li soi scofoni cū liste d veludo). Along with a black cape and a riding cloak made of cloth 'from the mountain' (una capa negra et un ferarolo de pano della montagna), these items totalled a value of 60 lire. ${ }^{92}$ Even simple items such as shoes could be important signifiers of identity and status, and the presence of fine materials, as well as matching items of colourful clothing, demonstrates a concern for style amongst those in the artisan class.

In a number of cases, the contents of these inventories can also be linked to the husbands' professions. Thus, the wives of carpenters, for example, had within their dotal inventories a greater number of, and more expensive pieces of, furniture, and the wives of bakers had a substantial number of tools used for baking. There are several more extreme examples when it comes to those who had relatives working in the clothing profession, as with Clara, wife of a hatter, whose inventory includes 200 caps or bonnets (berete). It is important to note that these caps were very cheap, with the whole sum of the 200 reaching only 10 lire, which within this inventory was the equivalent value of two carpets, and slightly less than the 11 lire for which one could purchase the four women's over-garments (vesture) 
listed. ${ }^{93}$ A similar example is in the inventory of Maria, wife of a shoemaker, which includes 150 pairs of shoes of different sorts, valued at 13 lire and 15 soldi. ${ }^{94}$ The most notable example in this sample comes from Lucretia, wife of a hatter, whose inventory includes 795 old caps, at a total value of 81 lire. ${ }^{95}$ Whilst these are exceptional examples, it is likely that items relating to the profession of the husband would have been used to bulk up the value of the inventory. In cases where the wives' assets were being secured against those of her husband, an artisan might choose to add value to his domestic items with goods from the workshop. Tools and merchandise were often also kept in the home, with many artisans living and working in the same area, living in rooms above their workshops (botteghe). Sandra Cavallo has highlighted the fluidity that existed between home and workshop spaces for artisans, particularly as much of women's work took place within the domestic setting. ${ }^{96}$ It is therefore perhaps no surprise that we can find many examples of workshop tools within these inventories. Catharina, wife of a potter, for example, had within her inventory 'worked wood of diverse sorts for the workshop and for the house' (legnami lavoradi de diverse sorte p bottega et casa), and 'iron of different sorts, similarly for the workshop and for the house' (feramenti de diverse sorte similiter p bottega et casa). ${ }^{97}$ These inventories also give an indication of women's work within the household, with many not only listing tools for the workshop, but also tools associated with tasks which were deemed to be 'women's work', such as weavers' looms and spinning wheels. ${ }^{98}$ Marina, daughter of a mason and wife of a man whose father was a spinner, for example, had in her dotal inventory three spinning wheels for silk (molineli da seda) ${ }^{99}$

\section{IV}

Jewellery was, and still is, a non-essential adornment of the body, yet evidence within these inventories suggests that it was an important element of artisan consumer culture in sixteenth- 
century Verona. Both artisans and nobility alike were able to use jewellery to enhance their public appearance and to project an image of respectability. However, it was also a tool of religious expression, with items such as rings, necklaces and pendants used as an extension of the devotional experience provided by the church, in the domestic environment. ${ }^{100}$ Still, throughout these inventories, there is a clear concern for the aesthetic, with a range of expensive and precious materials, such as gold, silver and gemstones, listed amongst more mundane household items. ${ }^{101}$

One of the most commonly found objects of jewellery in dotal inventories, which was both aesthetically and symbolically valuable, is the string (filza) of coral (corallo). Even in more simple forms, coral carried symbolic connotations and as such, this type of jewellery was not only an aesthetic addition to the dowry, but also deeply devotional. ${ }^{102}$ Corals were thought to have protective qualities, particularly associated with women and childbirth. Some of these filze may have been used as rosaries, kept upon the person and used for the counting of prayers. Evidence of rosaries can be found in inventories from across Italy as they became an increasingly popular consumer good during the Renaissance. ${ }^{103} 42$ of the sample mention at least one item with coral. Often, these were simple and inexpensive pieces, as was the case with the two coral necklaces in the inventory of Benedicta, wife of a swordsmith, valued at 1 lira and 10 soldi. ${ }^{104}$ However, there is ample evidence of necklaces of coral adorned with finer material, significantly increasing their value, both aesthetically and financially. Bartholomea, wife of a mason, had within her inventory, in addition to two simple rosaries, a necklace of coral with silver (una gola corali con un cor d'arzento et due corone), which were together valued at 8 lire. ${ }^{105}$ Similarly, Camilla, daughter of a mill keeper, and wife a spinner, had two strings of coral, one adorned with buttons of gold (bottoni d'oro) and one with crystals (cristalli), valued at 22 lire. ${ }^{106}$ 
Rings were equally significant, carrying with them not only financial value, but also religious and social associations, connected to marriage, status and wealth. ${ }^{107}$ When discussing the civility of Venice, Sansovino noted that there was no 'wretched person' who did not own rings. ${ }^{108} 47$ of the documents analysed contain at least one gold ring, with many noting more. Lucia, daughter of a butcher and wife of a barrel-maker, for example, had six gold rings of different sorts (aneli sei d'oro d piu sorte) in her dotal inventory, valued at 36 lire. ${ }^{109}$ Many rings in the sample also contained precious stones of different colours, such as those of Helena, wife of a wool worker, whose inventory includes a gold ring with an azure stone, as well as a silver ring with a red stone (uno anello doro con preda turchina et uno darzento con preda rosa). ${ }^{110}$ Like items of clothing made with precious fabrics, such jewellery could represent a significant financial outlay for a master craftsman. However, the frequency with which rings are listed in dotal inventories suggests that many artisans were willing to invest in non-essential items of personal adornment. Rings and other types of jewellery had become an important part of respectable identity for both males and females during the sixteenth century, and this was the case in Verona, as it was in Venice and other Renaissance centres.

Other items of religious jewellery, which added to the image of luxury and demonstrated personal piety, were frequently included in artisan dotal inventories. Gold and silver crucifixes worn around the neck were perhaps the most visible sign of one's devotion. Benedicta, whose inventory includes the simpler coral necklaces previously mentioned, also had a necklace of coral with a golden cross (gola de corali con una croseta d'oro), as well as a round necklace of silver (una gola de tondini d'arzento). ${ }^{111}$ Similarly Francesca, wife of a cheesemonger, had within her inventory a golden necklace with a cross (colane d'oro cō una croseta), valued at 11 lire. ${ }^{12}$ Also included are Agnus Dei, which were disks often made of wax and stamped with the image of the lamb of God. Sometimes, as in the case of Agneta, 
daughter of a barber and wife of a weaver, whose inventory includes a silver Agnus Dei (unus agnus dei argenti) valued at 13 lire and 10 soldi, more expensive materials were used. ${ }^{113}$ Such objects may have been used in conjunction with other items of devotion in order to facilitate private prayer, such as the religious paintings and artefacts that are scattered throughout the sample. Benedicta, the wife of a swordsmith, for example, had within her inventory a pot of holy water (stagnolo di otton da acqua santa), ${ }^{114}$ whilst Bartholomea, wife of a cobbler, also had a pot of holy water, as well as five paintings of the saints (cinque quadri diversi de imagine de santi). ${ }^{115}$

\section{V}

In the provincial Renaissance city of Verona, artisans were at the heart of the production of consumer culture. They played a central, though under-investigated role in the circulation and transmission of goods and ideas. Dowries were an important part of the exchange of goods amongst families and were tools for building relationships, as well as for publicly displaying the status of the family and social position of the new couple. They were thus a protected commodity which were frequently notarised, secured and ratified by the courts. The documentation arising from the protection of dowries can therefore not only tell us about the types of goods that women brought with them to marriage, but also about the types of goods women could rely upon as security should her funds be squandered. In the case of artisans, these goods were associated with the domestic environment, as well as the workshop. Whilst these inventories from the artisan class in Verona are certainly smaller than those of elites in cities such as Venice, they nevertheless demonstrate the active part artisans and their families played in the burgeoning market for consumer goods, and the emphasis that was placed on the acquisition of an abundance of material commodities. 
These inventories can provide an invaluable insight into the material world of 'ordinary' women and their families in provincial Renaissance cities. Whilst at times representing only a portion of the goods a couple might amass throughout their marriage, the inventories demonstrate that even at a basic level, artisan homes would have been filled with a vast array of essential and non-essential goods, used for both improving comfort and achieving splendour. The consistent pattern presented throughout the dotal inventories of artisans at various levels of the social scale suggests that, even for less well-off families, certain goods were nonetheless expected in a respectable household. Almost all of the inventories analysed contain similar items of furniture and clothing, as well as kitchen utensils and basic food items. Where artisans were able, they had the chance to augment their social standing by purchasing extra items for ornamentation and display, or simply by enriching their homes with quantities of particular pieces of furniture or clothing. This was at a time when artisans thought consciously about their public image and their portrayal of success. ${ }^{116}$ Items such as carved chests, items of silk, and golden crucifixes had both practical and symbolic purposes, but could also be used as tools by artisans to display their wealth, taste and devotion.

The evidence within the inventories suggests that the material world of the wives and daughters of artisans in sixteenth-century Verona was filled with furniture, clothing and other items necessary for running a successful home unit. It was also a world filled with splashes of colour and decoration, as well as fine items of clothing and jewellery. Being part of the artisan class, therefore, did not exclude women and their families from creating an honourable home environment, in which children were reared, guests hosted, and business conducted. ${ }^{117}$ 
${ }^{1}$ See, for example, Fernand Braudel, The structures of everyday life: the limits of the possible (Berkeley, 1992), p. 283. Others have argued that it was not until the Industrial Revolution that the popular classes were able to consume in a way which imitated elites; Neil McKendrick, John Brewer, and J. H. Plumb, The birth of consumer society: the commercialisation of eighteenth-century England (London, 1983). Paula Hohti notes that lower social groups have been 'largely excluded from the mainstream of Renaissance material culture history'; Hohti, “"Conspicuous” consumption and popular consumers: material culture and social status in sixteenth-century Siena', Renaissance Studies, 24 (2010), pp. 654-670, at p. 655.

${ }^{2}$ Hohti, “'Conspicuous” Consumption and popular consumers'.

${ }^{3}$ It has been argued that the rise of the artisan class and their 'consumer power' is 'one of the single most defining characteristics' of the early modern period; Catherine Richardson, Tara Hamling and David Gaimster, eds., The Routledge handbook of material culture in early modern Europe (Oxon, 2017). See also Richard A. Goldthwaite, Wealth and the demand for art in Italy (London, 1995) for a detailed discussion of the changes in the Italian economy that led to a consumer revolution. ${ }^{4}$ Ulinka Rublack, Dressing up: cultural identity in Renaissance Europe (Oxford, 2010), p. 6. It has also argued that dowries by their very nature encouraged upward social mobility within an increasingly competitive environment; Jutta Sperling, Convents and the body politic in late Renaissance Venice (Chicago, 1999).

${ }^{5}$ Stanley Chojnacki, 'Dowries and Kinsmen in Early Renaissance Venice', Journal of Interdisciplinary History, 4 (1975), pp. 571-600. See also Julius Kirshner and Anthony Molho, 'The dowry fund and the marriage market in early Quattrocento Florence', Journal of Modern History, 50 (1978), pp. 403-438 and Christiane Klapisch-Zuber, Women, family, and ritual in Renaissance Italy (Chicago, 1985).

${ }^{6}$ James Grubb, Provincial families of the Renaissance (Baltimore, 1996), p. 15.

${ }^{7}$ Diane Owen Hughes, 'From brideprice to dowry in Mediterranean Europe', Journal of Family History, 3 (1978), pp. 262-296, at p. 278. David Herlihy theorises that the fall of the brideprice in favour of the traditional dowry system was probably caused by an imbalance in the number of women 
of marriageable age compared to men; Herlihy, 'The medieval marriage market', Medieval and Renaissance Studies, 6 (1967), pp. 1-27. However, there remained a tradition of gift and counter gift in Renaissance Italy and rituals such as the husband 'clothing' his spouse were deeply embedded in the social fabric; Klapisch-Zuber, Women, family, and ritual, p. 222.

${ }^{8}$ Herlihy, 'The medieval marriage market', p. 5; Paola Lanaro, 'Les strategies patrimoniales familiales de l'élite vénitienne au XVIII ${ }^{\mathrm{E}}$ Siècle', Annales de Démographie Historique, 2 (2017), pp. $154-5$.

${ }^{9}$ Chojnacki, 'Getting back the dowry', in Women and men in Renaissance Venice: twelve essays on patrician society (Baltimore, 2000), pp. 97-8.

10 'Assicurazione si chiama anche l'atto, col quale la moglie si cauta e si assicura della sua dote sopra i beni del marito. Questo è un privilegio concesso dal nostro statuto alla dote, a sicurezza della quale sono ipotecati i beni del marito, dal momento che egli la riceve'; Marco ferro, Dizionario del diritto comune e Veneto (2 vols., Venice, 1845; orig. edn 1778-81), II, p. 165.

${ }^{11}$ Kirshner, 'Wives' Claims against Insolvent Husbands', in Kirshner and Suzanne Wemple, eds., Women of the medieval world: essays in honor of John H. Mundy (Oxford, 1985), p. 258.

${ }^{12}$ Chojnacki, 'From trousseau to groomgift', in Women and men in Renaissance Venice, p. 85.

${ }^{13}$ Stefania Montemezzo, 'La difesa di un diritto: le donne veronesei di fronte alla dote', in Paola Lanaro and Alison Smith, eds., Donne a Verona. Una storia della città dal medioevo a oggi (Verona, 2011), pp. 116-123, at p. 122.

${ }^{14}$ Kirshner, 'Wives' Claims against Insolvent Husbands', p. 257.

${ }^{15}$ Ibid., p. 297.

${ }^{16}$ Ibid., p. 298.

${ }^{17}$ Laura Castellazzi, ed., 'Rettori Veneti', Guida Agli Archivi di Stato - Verona, (Verona, 2000), p. 1254.

${ }^{18}$ Given the absence of folio numbers, each document will be identified by the date at the top of the source, which is the date that the document was expedited by the Venetian Rectors court. A common formula for these dates is as following: 'Expedita sub die 13 Maii 1570', for example. Many documents also include a second date, which is the date at which the dowry was originally transferred 
or agreed; however, not all documents include this date. The difference between the two dates was at times negligible, only a few days. However, sometimes it was a significant number of years, suggesting that at a certain point in the marriage a woman or her family, including at times her husband, felt the need to ratify and to protect the value of her dowry.

${ }^{19}$ Archivio di Stato di Verona (hereafter ASVr), Atti dei Rettori Veneti a Verona (hereafter ARV), busta (hereafter b.) 98, 9 July 1570, Magdalena, wife of Angeli Bartholomei fabri di Cogolo.

${ }^{20}$ Giorgio Riello, 'Things seen and unseen: the material culture of early modern inventories and their representation of domestic interiors', in Paula Findlen, ed., Early modern things: objects and their histories, 1500-1800 (Oxon, 2013), pp. 125-150.

${ }^{21}$ For a note on professional attributions, see Amelio Tagliaferri L'economia Veronese secondo gli estimi dal 1409 al 1635 (Milan, 1966), p. 76.

${ }^{22}$ James Farr, Artisans in Europe (Cambridge, 2000), p. 3.

${ }^{23}$ Paul Grendler has estimated that at the end of the sixteenth century, a master mason could earn 30 to 50 soldi a day in Venice, which equated to between 50 to 100 ducats a year, whilst assistants in the same workshop might earn only 20 soldi a day; Grendler, Aldus Manutius: humanist, teacher, and printer (Rhode Island, 1984), pp. 23-26. Note also the difference in Venetian and Veronese currency. The base currency in Verona during the period under investigation is the lira di piccolo di Verona, a currency of account. 1 lira is equivalent to 20 soldi and this in turn is the equivalent to 240 denari. 3 lire di piccolo di Verona corresponds to 4 Venetian lire di piccolo; Edoardo Demo, "L'anima della città" L'industria tessile a Verona e Vicenza (1400-1550), (Milan, 2001), p. 21.

${ }^{24}$ James Farr, Hands of honor: artisans and their world in Dijon, 1550-1650 (Ithaca, 1988), p. 10.

${ }^{25}$ Evelyn Welch, Shopping in the Renaissance: consumer cultures in Italy, 1400-1660 (London, 2009), pp. 130-2.

${ }^{26}$ For detailed glossary of professions in Verona see Tagliaferri, L'economia Veronese, pp. 207-216.

${ }^{27}$ Jan de Vries, The Industrious Revolution: consumer behaviour and the household economy, 1650 to the present (New York, 2008). 
${ }^{28}$ Renata Ago, translated by Bradford Bouley and Corey Tazzara, with Paula Findlen, Gusto for things: a history of objects in seventeenth-century Rome (London, 2013). See also Lorna Weatherill, Consumer behaviour and material culture in Britain, 1660-1760 (London, 1988).

${ }^{29}$ Goldthwaite, Wealth and the demand for art in Italy.

${ }^{30}$ Whilst every inventory analysed also included items of table and kitchenware, such as pots, pans and spoons, these have not been included in this discussion.

${ }^{31}$ Roberts, argues that for the elite, beds conferred social status and were built to be passed down through generations, demonstrating both financial power and fashionable taste; Sasha Roberts "Let me the curtains draw": the dramatic and symbolic properties of the bed in Shakespearean tragedy', in Jonathan Gil Harris and Natasha Korda, eds., Staged properties in early modern English drama (Cambridge, 2002), pp. 153-175.

${ }^{32}$ Cavallo also notes that many artisans in Renaissance Genoa had a high number of beds within their household inventories, which she argues is a reflection of the transitory nature of artisan lifestyles and family structures, with many sons, daughters and relatives, leaving home and then returning for intermittent periods; Sandra Cavallo, 'The artisan's casa', in Ajmar-Wollheim and Dennis, eds., At home in renaissance Italy (London, 2006), pp. 66-76, at p. 73.

${ }^{33}$ Peter Thornton, The Italian Renaissance interior (London, 1991), p. 111.

${ }^{34}$ Lettiere were large pieces of furniture and were distinguished from normal beds in that they had tall headboards, capped with a cornice; Thornton, The Italian Renaissance interior, p. 114.

${ }^{35}$ Paula Hohti, 'Material culture, shopkeepers and artisans in Sixteenth-Century Siena' (unpublished $\mathrm{PhD}$ thesis, University of Sussex, 2006).

${ }^{36}$ ASVr, ARV, b. 98, 20 Oct. 1569, Appolonie, daughter of Franisci pistoris and wife of Bartholomei pistori.

${ }^{37}$ ASVr, ARV, b. 106, 26 Nov. 1573, Margerita, wife of Isepo de Zonzi spadaro, daughter of Zanbatista flaminio.

${ }^{38}$ ASVr, ARV, b. 149, 20 Dec. 1595, Catherina, wife of Battista calzarer of Mantua.

${ }^{39}$ Cavallo, 'The Artisan's Casa', p. 73 
${ }^{40}$ ASVr, ARV, b. 96, 8 Jan. 1567, Barbere daughter of Michele pistoris and wife of Pauli intagliatoris.

${ }^{41}$ ASVr, ARV, b. 96, 18 June 1566, Floris de belle, daughter of Joannis Avanzoni and wife of Antonii pistoris.

${ }^{42}$ ASVr, ARV, b. 149, 6 Feb. 1596, Anna, wife of Bartolamio Zaneti filatorio.

${ }^{43}$ The link to Germany is mentioned a number of times within this sample. This is significant as Verona was seen as the gateway for trade with the Holy Roman Empire and had strong links with cities such as Augsburg and Nuremberg. From this evidence, it seems that artisans were involved in the consumption of goods from the North. ASVr, ARV, b. 98, 20 June 1570, Libera, daughter of Laurentio sartor and wife of Calisto pistor.

${ }^{44}$ Thornton argues that canopied structures indicated high rank for the person who slept in the bed and this was often associated with princely culture; Thornton, The Italian Renaissance interior, p. 125.

${ }^{45}$ Claudio Paolini, 'Chests', in Ajmar-Wollheim and Dennis, eds., At home in Renaissance Italy, pp. $120-122$.

${ }^{46}$ ASVr, ARV, b.106, 26 Nov. 1573, Margerita, wife of Isepo di Zonzi spadaro and daughter of Zanbatista flaminio.

${ }^{47}$ ASVr, ARV, b. 96, 6 Mar. 1567, Clara, daughter of Floravanti di Zavasifis and wife of Franco di Schedo biretarii.

${ }^{48}$ The abundance of colour in artisan households is also something that has been noted by Isabella Palumbo Fossati Casa in 'L'interno della casa dell'artigiano e dell'artista nella Venezia del cinquecento', Studi Veneziani, 8 (1984), pp. 109-153.

${ }^{49}$ ASVr, ARV, b. 98, 12 July 1570, Lucia, daughter of Belini de bovevaria and wife of Bartholomei tinctoris biretoris.

${ }^{50}$ The camera was a multi-purpose domestic space, usually where the bed was kept. The portego was a reception room, sometimes a large hallway in the centre of the house, used to receive family and guests.

${ }^{51}$ Hohti, “"Conspicuous” consumption and social status in sixteenth-century Italy’, p. 666. 
${ }^{52}$ Razzall has drawn attention to the literary and symbolic associations of containers in early modern literature; Lucy Razzall, 'Containers and containment in early modern literature' (unpublished PhD thesis, University of Cambridge, 2012).

${ }^{53}$ Francesco Sansovino, Venetia città nobilissima, translated and quoted in Fortini-Brown, Private lives in Renaissance Venice: art, architecture, and the family (New Haven, 2005), p. 3.

${ }^{54}$ See Tessa Storey, Carnal commerce in Counter-Reformation Rome (Cambridge, 2008); Raffaella Sarti, translated by Allan Cameron, Europe at home: family and material culture, 1500-1800 (New Haven, 2002).

${ }^{55}$ ASVr, ARV, b. 98, 20 June 1570, Libera, daughter of Laurentino sarto and wife of Calistro pistor; ASVr, ARV, b. 120, 4 Feb. 1580, Camilla wife of Bartholomeo pelizzar.

${ }^{56}$ ASVr, ARV, b. 98, 31 Aug. 1570, Diamante daughter of Zanetto di calzareri and wife of Francesco Bonaventura caliaro.

${ }^{57}$ Ago notes how in eighteenth-century Rome, the Ugolini household, which was large enough to have eighteen rooms, contained 74 different chairs. She argues that lower down the social scale, houses with smaller numbers of rooms did not have the capacity to accommodate large number of desks, and this is reflected in the smaller number of chairs. This was evidently the case for artisans, whose homes would have been, on the whole, very small. Yet, in relation to the size of a small artisan home, the number of chairs listed in the inventories is striking. See Ago, Gusto for things, p. 85. ${ }^{58}$ Storey notes how in Counter-Reformation Rome, prostitutes often had an abundance of chairs in their homes, which were used for entertaining a variety of guests. The higher the status of the prostitute, the grander her seating was expected to be; Storey, Carnal Commerce. On the importance of chairs to sociability, see also Mimi Hellman, 'Furniture, sociability, and the work of leisure in 18th-century France', Eighteenth-Century Studies, 32 (1999), pp. 415-45.

${ }^{59}$ Ajmar-Wollheim and Dennis, eds., At home in Renaissance Italy. See also Timothy Wilson, 'Maiolica on the credenza' in Maiolica: Italian Renaissance ceramics in the Metropolitan Museum of $\operatorname{Art}$ (New York, 2016).

${ }^{60}$ François Quiviger, The sensory world of Italian Renaissance Art (London, 2010), p. 159. 
${ }^{61}$ ASVr, ARV, b. 106, 6 May 1573, Francesca, daughter of Leonardi masoni and wife of Jon Petri formagerii.

${ }^{62}$ ASVr, ARV, b. 98, 20 June 1570, Libera, daughter of Laurentino sartor and wife of Calisto pistor.

${ }^{63}$ ASVr, ARV, b. 106, 6 May 1573, Francesca, daughter of Leonardi masoni and wife of Jon Petri formagerii.

${ }^{64}$ Julia Poole, Italian maiolica (Melbourne, 1997), p. 5. See also Dora Thornton and Timothy Wilson, Italian Renaissance ceramics: a catalogue of the British Museum collection (London, 2009).

${ }^{65}$ Poole notes how the Este of Ferrara started to order maiolica by the early sixteenth century, suggesting a significant rise in its status as a commodity; Poole, Italian maiolica, p. 5.

${ }^{66}$ Poole refers to the 'great boom' in the production of maiolica during the Renaissance in Italian maiolica, p. 3. See also Luke Syson and Dora Thornton, Objects of virtue: art in Renaissance Italy (London, 2001), p. 200.

${ }^{67}$ Peter Burke, The historical anthropology of early modern Italy (Cambridge, 1987), p. 132.

${ }^{68}$ Cavallo argues that in Renaissance Genoa, clothes were the most valuable part of an artisan's assets; Cavallo, 'The artisan's casa', p. 72.

${ }^{69}$ It has been argued that 'a passion for fashion' became a wide social phenomenon in the early modern period, with clothing used as a tool in an effort to project particular identities; Ulinka Rublack and Maria Hayward, eds., The first book of fashion: the book of clothes of Matthäus \& Veit Konrad Schwarz of Augsburg (London, 2015). See also Giorgio Riello, 'Fabricating the domestic: the material culture of textiles and the social life of the home in early modern Europe', in Beverly Lemire, ed., The force of fashion in politics and society: global perspectives from early modern to contemporary times (Helsinki, 2006), pp. 41-66.

${ }^{70}$ Patricia Allerston, 'Clothing and early modern Venetian society', Continuity and Change, 15 (2000), pp. 367-390, at p. 375. See also Robert Davis, Shipbuilders of the Venetian Arsenal (London, 1991).

${ }^{71}$ ASVr, ARV, b. 106, 6 Aug. 1573, Catharina daughter of Gregorio di Crisponi, and wife of Domengo bussolar.

${ }^{72}$ ASVr, ARV, b. 98, 10 Dec. 1569, Simona, wife of Baptista sartor. 
${ }^{73}$ Hohti, ““Conspicuous” consumption and social status in sixteenth-century Italy', p. 666.

${ }^{74}$ Demo notes that by 1571 , Veronese merchants had over 100,000 ducats of credit after selling silk to markets in 'Bolzano, Antwerp, Lyons, London and Nuremberg', and looms within the city produced around 45-50 tons of silk between 1581 and 1589; Demo, 'Wool and silk. The textile urban industry of the Venetian Mainland (15th-17th Centuries)', in Paola Lanaro, ed., At the centre of the old world: trade and manufacturing in Venice and on the Venetian mainland, 1400-1800 (Toronto, 2006), pp. 231-237, at p. 231.

${ }^{75}$ This number excludes those inventories which include items where the status of the fabric is ambiguous. The fabric zambelletto, for example, is mentioned frequently in the sample. Zambelletto, or camlet, was a ribbed fabric made of a combination of materials, which could be given a watered finish to make it appear like silk, without actually being silk. However, some zambelletto fabrics were made with silk, particularly within Venice and the Venetian Empire. Such a name could therefore refer to woollen or silk cloth and thus has not been included in the figure.

${ }^{76}$ ASVr, ARV, b. 106, 6 Aug. 1573, Catharina daughter of Gregorio di Crisponi and wife of Domengo bussolar.

${ }^{77}$ ASVr, ARV, b. 93, 8 Jan. 1564, Joana, wife of Mathei textoris.

${ }^{78}$ ASVr, ARV, b. 149, 6 Feb. 1596, Anna wife of Bartolamio Zaneti filatorio.

${ }^{79}$ Rublack has noted how black fabrics had particular associations with high status in early modern cities; Rublack, Dressing up: cultural identity in Renaissance Europe.

${ }^{80}$ Mola notes how in the year 1555-56, 24 bolts of black velvet were produced in Verona. This then increased to 63 bolts in 1556-57, before falling off slightly in 1557-58, and recovering to 97.5 bolts in 1558-69. Luca Mola, The silk industry of Renaissance Venice (London, 2000), p. 273.

${ }^{81}$ ASVr, ARV, b. 98, 7 Dec. 1569, Iseppa daughter of Simon molinar and wife of Constatio filatorio Milanese.

${ }^{82}$ ASVr, ARV, b. 98, 23 May 1570, Camilla daughter of Bernardini molendinarii and wife of Joannis filatorii.

${ }^{83}$ Cesare Vecellio, Habiti antichi et moderni: the clothing of the Renaissance world, Europe, Asia, Africa and the Americas, ed. and trans. Margaret F. Rosenthal and Ann Rosalind Jones (London, 
2008), p. 106.

${ }^{84}$ ASVr, ARV, b. 120, 4 Feb. 1580, Camilla, wife of Batolomeo pelizzar; ASVr, ARV, b. 112, 27 June 1577, Isabeta, wife of Micheli forasoi pistor.

${ }^{85}$ ASVr, ARV, b. 98, 10 Dec. 1569, Simona, wife of Baptiste sartor.

${ }^{86}$ ASVr, ARV, b. 104, 12 Nov. 1570, Madalena, daughter of Dominici molendinarii and wife of Angeli molendinari.

${ }^{87}$ ASVr, ARV, b. 98, 14 Feb. 1570, Domenica, daughter of Antoni Peregrini and wife of Dominice textoris.

${ }^{88}$ ASVr, ARV, b. 106, 22 Aug. 1573, Ingele daughter of Martini marangoni and wife of Cesaris marangoni.

${ }^{89}$ Many, including Smith, have stressed that the division between fine arts and decorative and domestic arts is an entirely a modern creation; Pamela Smith, The body of the artisan: art and experience in the scientific revolution (Chicago, 2004), p. 27. Rublack has similarly argued that to recover the 'visual experience of people in the Renaissance', we must look at a range of artefacts from high end painting, to clothing, shoes, hats and other seemingly mundane items; Ulinka Rublack, 'Matter in the material Renaissance', Past and Present, 219 (2013), 41-85.

${ }^{90}$ ASVr, ARV, b. 96, 10 July 1567, Bartholomea daughter Bartholomei cagiate di Beneronia and wife of Francisci murarii.

${ }^{91}$ ASVr, ARV, b. 98, 20 June 1570, Libera daughter of Laurentio sartor and wife of Calisto pistor.

${ }^{92}$ ASVr, ARV, b. 98, 20 Oct. 1569, Appolonie, daughter of Francisci pistoris and wife of Bartholomei pistoris.

${ }^{93}$ ASVr, ARV, b. 96, 6 Mar. 1567, Clara, daughter of Floravanti di Zavasifis and wife of Franco di Schedo biretarii.

${ }^{94}$ ASVr, ARV, b. 96, 24 Nov. 1561, Maria, daughter of Zorzo di Angeli di Voltolina and wife in second marriage to Gerardo calzarero.

${ }^{95}$ ASVr, ARV, b. 98, 12 Jan. 1570, Lucretia, daughter of Jacobi gipfi and wife of Laurentii biretarii.

${ }^{96}$ Cavallo, 'The artisan's casa', p. 70. 
${ }^{97}$ ASVr, ARV, b. 106, 6 Aug. 1573, Catharina daughter of Gregorio di Crisponi, and wife of Domengo bussolar.

${ }^{98}$ For debate surrounding women's work see Lyndal Roper, The holy household: women and morals in Reformation Augsburg (Oxford, 1989) and Amanda Vickery, 'Historical review. Golden age to separate spheres? A review of the categories and chronology of English women's history', The Historical Journal, 35 (1003), pp. 383-414. See also Beatrice Zucca Micheletto, 'Reconsidering the southern European model: Dowry, women's work and marriage patterns in pre-industrial urban Italy (Turin, second half of the $18^{\text {th }}$ century), The history of the family, 16 (2011), pp. 354-370.

${ }^{99}$ ASVr, ARV, b. 96, 4 Mar. 1567, Marina, daughter of Petri d Paderamo murarii and wife of Jacobi. ${ }^{100}$ On the importance of the materiality of religion within the Italian Renaissance home, see Maya Corry, Deborah Howard and Mary Laven, eds., Madonnas and miracles: the holy home in Renaissance Italy (London, 2007).

${ }^{101}$ Irene Galandra Cooper and Mary Laven reject the idea that Renaissance commodification led to secularisation. Instead, they argue that devotion and worldliness should not be polarised. Commodification often went side-by-side with devotion; Galandra Cooper and Laven, 'The material culture of piety in the Italian Renaissance: re-touching the rosary', in Richardson, Hamling and Gaimster, eds., Routledge handbook of material culture in early modern Europe, pp. 338-353. ${ }^{102}$ Jacqueline Musacchio, 'Lambs, coral, teeth, and the intimate intersection of religion and magic', in Sally J Cornelison and Scott Bradford Montgomery, eds., Images, relics, and devotional practices in late medieval and Renaissance Italy (Ariz, 2006), pp. 139-156. See also Galandra Cooper, 'Materiality of domestic devotion' (unpublished $\mathrm{PhD}$ thesis, University of Cambridge, 2017) and Giovanni Tescione, Italiani alla pesca del corallo (Naples, 1968).

${ }^{103}$ Ibid., p. 340.

${ }^{104}$ ASVr, ARV, b. 106, 20 Aug. 1573, Benedicta, daughter of Nicolini de Nicolinis and wife of Antonii spatarii.

${ }^{105}$ ASVr, ARV, b. 96, 10 July 1567, Bartholomea daughter of Bartholomei cagiate di Beneronia and wife of Francisci murarii. 
${ }^{106}$ ASVr, ARV, b. 98, 23 May 1570, Camillam daughter of Bernardini molendinarii del Piva de Brayda and wife of Joannis filatorii.

${ }^{107}$ Jack Hinton, 'By sale, by gift: aspects of the resale and bequest of goods in late-sixteenth-century Venice', Journal of Design History, 15 (2002), p. 245. See also Katie Tycz, 'Mourning rings', in Victoria Avery, Melissa Calaresu and Mary Laven, eds., Treasured possessions: from the Renaissance to the Enlightenment (London, 2015), pp. 235-237.

${ }^{108}$ See Bella Mirabella, ed., Ornamentalism: the art of Renaissance accessories (Michigan, 2011). ${ }^{109}$ ASVr, ARV, b. 106, 27 June 1573, Lucia, daughter of Lazan beccarii and wife of Antonio Pretossi brentarii.

${ }^{110}$ ASVr, ARV, b. 106, 21 Nov. 1573, Helene, wife of Jacobi scartezini.

${ }^{111}$ ASVr, ARV, b. 106, 20 Aug. 1575, Benedicta, daughter of Nicolini de Nicolinis and wife of Antonii spatarii.

${ }^{112}$ ASVr, ARV, b. 106, 6 May 1573, Francesca, daughter of Leonardi masoni and wife of Jon Petri formagerii.

${ }^{113}$ ASVr, ARV, b. 96, 27 Mar. 1566, Agneti, daughter of Vectoris barberii and wife of Matthei Lipelle textoris panorum. Musacchio has noted the frequent grouping of more obviously sacred objects such as the Agnus Dei and the cross, with amulet-like objects such as coral; Musacchio, 'Lambs, Coral, Teeth, and the Intimate Intersection of Religion and Magic'. See also Galandra Cooper 'Investigating the "case" of the Agnus Dei in sixteenth-century Italian Homes', in Maya Corry, Marco Faini, and Alessia Meneghin, eds., Domestic devotions in early modern Italy (Leiden, 2017), pp. 220-243.

${ }^{114}$ ASVr, ARV, b. 106, 22 Aug. 1573, Ingele daughter of Martini marangoni and wife of Cesaris marangoni.

${ }^{115}$ ASVr, ARV, b. 135, 3 Jan. 1590, Bartholomea, daughter of Joannis Baptista Cavalarii and wife of Dominici Bontempi cerdonis.

${ }^{116}$ Stephen Greenblatt, Renaissance self-fashioning: from More to Shakespeare (London, 2005). 